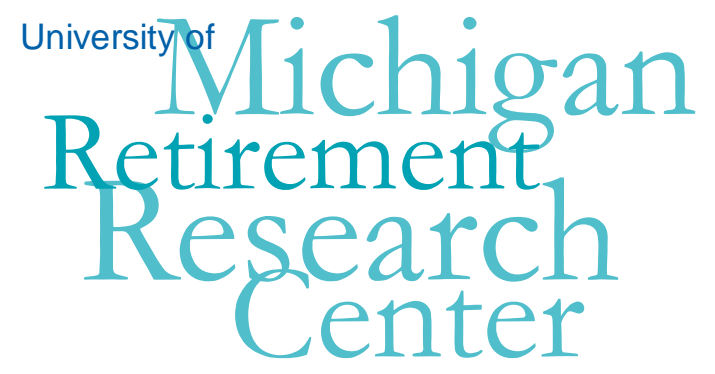

Working Paper

WP 2010-235

\title{
Personality, Lifetime Earnings, and Retirement Wealth
}

Angela Lee Duckworth and David R. Weir

\begin{tabular}{|l|l|}
\hline $\mathrm{M}$ & $\mathrm{R}$ \\
\hline $\mathrm{R}$ & $\mathrm{C}$ \\
\hline
\end{tabular}

Project \#: UM10-13 


\title{
Personality, Lifetime Earnings, and Retirement Wealth
}

\author{
Angela Lee Duckworth \\ University of Pennsylvania \\ David R. Weir \\ University of Michigan \\ October 2010
Michigan Retirement Research Center
University of Michigan
P.O. Box 1248
Ann Arbor, MI 48104
http://www.mrrc.isr.umich.edu/
(734) 615-0422

\section{Acknowledgements}

This work was supported by a grant from the Social Security Administration through the Michigan Retirement Research Center (Grant \# 10-M-98362-5-01). The findings and conclusions expressed are solely those of the author and do not represent the views of the Social Security Administration, any agency of the Federal government, or the Michigan Retirement Research Center.

\section{Regents of the University of Michigan}

Julia Donovan Darrow, Ann Arbor; Laurence B. Deitch, Bingham Farms; Denise Ilitch, Bingham Farms; Olivia P. Maynard, Goodrich; Andrea Fischer Newman, Ann Arbor; Andrew C. Richner, Grosse Pointe Park; S. Martin Taylor, Gross Pointe Farms; Katherine E. White, Ann Arbor; Mary Sue Coleman, ex officio 


\title{
Personality, Lifetime Earnings, and Retirement Wealth
}

\begin{abstract}
Studies of adolescents and young adults have shown that schooling impacts economic outcomes beyond its impact on cognitive ability. Research has also shown that the personality trait of conscientiousness predicts health outcomes, academic outcomes, and divorce. Using the Big Five taxonomy of personality traits, this study examines whether non-cognitive traits are related to economic success over the life course. Examining Health and Retirement Study survey data linked to Social Security records on over 10,000 adults age 50 and over, we investigate the relationship of personality traits to economic outcomes. Controlling for cognitive ability and background variables, do more conscientious and emotionally stable adults have higher lifetime earnings, and is this due to higher annual earnings, longer work lives, or both? Do more conscientious adults save a higher proportion of their earnings for retirement, and does conscientiousness of each partner in a married couple matter? Do conscientiousness and emotional stability interact such that the effects of conscientiousness are greater among less emotionally stable adults?
\end{abstract}

\section{Authors’ Acknowledgements}

The research reported herein was pursuant to a grant from the U.S. Social Security Administration (SSA) funded as part of the Retirement Research Consortium (RRC). The findings and conclusions expressed are solely those of the authors and do not represent the views of SSA, any agency of the Federal Government, the RRC, or the Michigan Retirement Research Center. The Health and Retirement Study (HRS) is sponsored by the National Institute on Aging (U01AG009740) and is conducted by the University of Michigan. 


\section{Introduction}

There is increasing interest among economists in how "non-cognitive" traits affect economic behavior and outcomes. This is motivated in part by evidence from adolescence and young adulthood that schooling has effects on economic outcomes that go beyond its impact on IQ or other measures of cognitive abilities, and which appear to be mediated by other measurable traits (Heckman, Stixrud, and Uzua, 2006). An important open question is whether these traits and their effects have a durable impact on economic success over a lifetime. Given the wide observed variation in retirement wealth conditional on lifetime earnings (Venti and Wise, 1998), we might also want to know whether similar non-cognitive traits influence wealth accumulation. Given the scarcity of true longitudinal data linking early life cognitive and non-cognitive traits to well-measured lifetime outcomes (though see Judge, et al., 1999), we explore these questions by looking for associations between lifetime outcomes and psychological measures taken later in life. Clearly, this sort of observation on its own cannot establish a causal influence from personality to economic success. However, given the evidence on causal connections early in life, the presence of an association late in life would tend to support the view that personality has a durable impact on economic success and that human capital investments in noncognitive skills have real value (Cunha and Heckman, 2007).

The term "non-cognitive" is broad and encompasses a range of measures including concepts like self-esteem that have a worrisome degree of dependence on the outcomes we seek to study. We focus on personality traits that are relatively stable patterns of thinking, feeling, and acting. In psychology, personality is generally considered to comprise five broad families of traits: extroversion, agreeableness, openness, conscientiousness, and neuroticism (or its converse, emotional stability). Personality as measured by the Big Five is not immutable, but within-person correlations tend to be about $r=.75$ by the fifth decade of life (Roberts and DelVecchio, 2000). There is also evidence for heritability of 
personality traits (Krueger and Johnson, 2008), though as yet no consistent findings on specific genetic determinants (Terracciano, et. al., 2010).

Of the five families of traits in the Big Five taxonomy of personality, conscientiousness is the best predictor of health outcomes (Friedman et al., 1993; Hampson, et al., 2007; Roberts et al., 2007), academic outcomes (Poropat, 2009), and divorce (Roberts et al., 2007). Conscientiousness refers to a family of personality traits including industriousness, dependability, and organization. Emotional stability has also been found to be related to better outcomes. However, Roberts et al. (2009) found an interaction between neuroticism and conscientiousness suggesting possible benefits of low emotional stability. Specifically, older adults who were both high in conscientiousness and low in emotional stability were physically healthier than others.

The Health and Retirement Study (HRS) presents an unparalleled opportunity to study the association of personality with lifetime economic success. The linkage of HRS survey data with administrative data from the Social Security Administration allows us to look at well-measured lifetime earnings rather than self-reported outcomes in a single year or short period. The wealth data in HRS allow us to look at retirement savings conditional on lifetime earnings. Together, these measures represent the most essential aspects of lifetime economic success. The HRS also measures cognitive abilities and educational attainment, allowing us to control for these and other determinants of economic success. The HRS began collecting data on personality in 2006 as part of a self-administered questionnaire on psychosocial characteristics. Half the sample was given the questionnaire in 2006 and the other half in 2008. 


\section{Hypotheses}

We began with three research questions based on previous findings in the literature and our theoretical expectations about links between personality traits, labor market valuations, and economic behavior.

1.) Lifetime Earnings. Controlling for cognitive ability and background variables, do more conscientious and emotionally stable adults have higher lifetime earnings, and is this due to higher annual earnings, longer work lives, or both?

2.) Interaction Effects. Do conscientiousness and emotional stability interact such that the effects of conscientiousness are greater among less emotionally stable adults?

3.) Retirement Savings. Do more conscientious adults save a higher proportion of their earnings for retirement, and does conscientiousness of each partner in a married couple matter?

\section{Data and Methods}

Our sample derives from the 2006 and 2008 waves of HRS. To be included, a respondent had to complete the self-administered questionnaire with personality measures in either 2006 or 2008, and to be included in the linked Social Security administrative records.

Personality was measured using a 26-item questionnaire developed for the Midlife Development Inventory (Lachman \& Bertrand, 2001). HRS participants used a 4-point rating scale to endorse 26 adjectives corresponding to Big Five personality traits of conscientiousness, emotional stability, agreeableness, extraversion, and openness to experience (Clarke, et al, 2008). A total of 14,500 respondents completed the questionnaires. The items for these scales are listed in the Appendix. 
Lifetime earnings come from the linked Social Security records available for 20,777 respondents (10,731 of whom survived to 2006 and provided a personality questionnaire). To construct lifetime earnings we began with the AIME calculated for each individual in the linked records. AIME adjusts nominal earnings in past years to constant dollars in the year the individual turned 60 using SSA's wage index. We then further adjusted all AIME values to constant 2006 dollars using the CPI and multiplied by $(12 \times 35=420)$ to get lifetime total earnings. Note that this is lifetime Social Security earnings, not total earnings. Earnings above the Social Security taxable maximum are not included, and only the 35 highest earning years are included.

At some later time we hope to have good estimates of earnings not included in reported Social Security earnings to re-evaluate our findings. There are two primary reasons to be concerned about using lifetime SS earnings. One is that earnings above the taxable maximum are not counted. This truncates somewhat the highly skewed distribution of earnings and is not a major concern if the focus is on low earnings as a problem for retirement security. The taxable maximum has risen over time relative to median earnings so a larger percentage of total earnings of younger cohorts will be counted. We use statistical controls for cohort and birth year to capture this effect. The second concern is that earnings from work in sectors not covered by Social Security is not counted. This is potentially a more serious concern as some persons may appear to be low lifetime earners because of years spent in uncovered sectors. We attempted to address this by limiting the analysis to respondents whose self-reported lifetime years of work were more than five or more than ten years longer than shown on the administrative record. This did not substantively change our results of interest and we do not show those results here.

Wealth in the HRS is measured at the level of the household, which means that for couples we cannot assign wealth to any one individual and the appropriate unit of analysis is the household. We 
therefore analyze couples separately from single-person households and are able to examine effects of both personalities in the couple. We use aggregate financial wealth measured in 2006 or 2008 as our measure of wealth and model savings in two ways: with log wealth as the dependent variable and lifetime earnings as a control variable in the regression, and with the ratio of wealth to earnings as the dependent variable.

In all regression analyses we controlled for birth year, sex, ethnicity, HRS entry cohort, years of education, and four cognitive measures: episodic memory (sum of immediate and delayed word recall), mental status (backward counting task), numeracy, and vocabulary. Ideally, we would like to have cognition measures at the same age on everyone. We took the first observation in the panel on each of these cognitive measures to minimize the impact of age-related decline.

\section{Results}

Lifetime Earnings. Table 1 shows the central findings on individuals' lifetime earnings. We find that more conscientious and emotionally stable (i.e., less neurotic) adults have higher lifetime earnings. The dependent variable is in logs and the personality variables are standardized z-scores. Thus, the coefficient of .09 on conscientiousness indicates that a one standard deviation increase in conscientiousness is associated with a $9 \%$ increase in lifetime earnings. A one standard deviation increase in emotional stability is associated with a 5\% increase in lifetime earnings. The other three Big Five factors did not show significant relationships to lifetime earnings.

These findings on non-cognitive skills can be compared with the estimated effects of cognitive abilities. Memory is the most sensitive to age-related decline and that may explain why it has limited apparent effect in these models—-for the older cohorts our first memory test was at 70 or older. However, vocabulary ability is often considered to be "crystallized” intelligence and to decline very 
little with age and it has no association with earnings. The cognitive abilities most related to processing speed (mental status, based on backward counting tasks) and numerical abilities (numeracy based on three word problems) showed the strongest relationship to earnings. Each of those two measures had effect sizes comparable to that of conscientiousness.

It is important to note that these effects of cognitive and non-cognitive skills are net of the effects of education in this model. One year of education raises lifetime earnings by about $5 \%$. The other control variables in the model show expected effects. Women and Hispanics have lower lifetime earnings. Interestingly, with controls for education, cognitive and non-cognitive skills there is no blackwhite differential in lifetime Social Security earnings.

Tables 2 and 3 repeat this model separately on the two components of lifetime earnings: average annual earnings, and years of work. Overall, the average annual earnings is the more important determinant of lifetime earnings and is better explained by the covariates in the model. Years of work and average earnings are positively correlated and typically most covariates affect both in the same direction and relative orders of magnitude. One standard deviation of conscientiousness raises average earnings by $\$ 1500$ (about $5 \%$ of the mean of $\$ 30,000$ ), which is slightly lower than the effect of numeric ability. Greater emotional stability raises annual earnings by about $\$ 700$, which is less than the effect of mental status. Women earned $\$ 20,000$ per year less than men over their lifetimes, which is about half the average earnings of men. Turning to years of work, women worked six years less than men, further contributing to lower lifetime earnings. Conscientiousness was associated with an increase of .36 years of work, just over $1 \%$ of the average of 28 years. Emotional stability and the cognitive abilities also raised years of work, and also by proportionally less than their influence on average earnings.

We find, then, that personality measures account for nearly as much variation in lifetime earnings and its components as do cognitive measures. In models that exclude education the effect 
estimates for the cognition variables increase while the personality measures are largely unchanged. This reflects a stronger correlation of education with the numeric ability and processing speed variables than it has with personality.

Interaction effects. The one interaction model we present here is in Table 4, testing whether conscientiousness and emotional stability compensate for one another. We find that they do, one standard deviation increase above the mean in emotional stability decreases the impact of conscientiousness on lifetime earnings from $9 \%$ to $6 \%$, whereas a one standard deviation decrease in emotional stability below the mean raises the impact of conscientiousness from $9 \%$ to $12 \%$.

Retirement Savings An important issue for retirement security is savings out of lifetime earnings. We focus here on married couples because most people retire as part of a married couple and because there is some interest in how the personalities and abilities of spouses contribute to their joint savings. We estimate two models to test these effects. The first uses the log of financial wealth as the dependent variable and includes the log of combined lifetime earnings of husband and wife as a righthand side variable. The second takes the log of the ratio of financial wealth to combined lifetime earnings as the dependent variable (in effect forcing the coefficient on log earnings to be one). Generally speaking, the effects of personality and cognitive variables are similar in the two models.

In Table 5 we see that the conscientiousness of husbands and wives have essentially equal effects on wealth, with one standard deviation raising married couple wealth by $14 \%$. That effect is the same as the effect of husband's numeric ability, which is the largest of the cognition measures. Wife's conscientiousness is a much more significant influence on couple wealth than any other characteristic of the wife except her education. In contrast to the findings for lifetime earnings, neuroticism is not closely linked to wealth accumulation, but agreeableness of both husband and wife tend to lower wealth. One of the components of agreeableness is "softhearted" and perhaps this characteristic works against savings 
or high-return investing. The coefficient on log earnings is only .41, consistent with other work that wealth accumulation is not simply a one-to-one relationship with earnings. We can also examine retirement wealth by looking at the ratio of wealth to earnings in Table 6. Generally speaking, the same pattern of relationships is found as in Table 4.

Assortative mating The simple linear models used here do not examine interaction effects such as might arise with assortative mating. Personality characteristics do not have exceptionally strong correlations across spouses. Conscientiousness is correlated at .15 and neuroticism at .07. Openness has the strongest correlation at .24. Cognitive abilities have slightly stronger correlations (numeracy and mental status both at .26, and memory at .25). Education is much more strongly correlated at .6.

\section{Discussion}

In a large, nationally representative sample of older American adults, the personality traits of conscientiousness and emotional stability are related to objective measures of economic success independently of education and cognitive ability.

Our findings are consistent with previous findings of a small-sample, longitudinal study investigating personality and self-reported economic success. Judge et al. (1999) studied 350 individuals from early childhood to retirement. Controlling for childhood IQ, childhood conscientiousness was the strongest predictor of a composite measure of self-reported income and occupational status. Notably, the variance explained in this composite measure by childhood conscientiousness $(\beta=.44)$ was comparable to that explained by childhood IQ $(\beta=.41)$. Agreeable children were less successful $(\beta=-.32)$, and emotionally stable $(\beta=.21)$ and extraverted $(\beta=.27)$ children were more successful.

We note a serious limitation of our analysis is the timing of personality assessment. Personality traits in the HRS were measured largely after the production of the measured economic outcomes. 
There is thus reason to worry about reverse causality. Individuals who observe that they have not earned, worked, or saved as much as others may be influenced by such observations to believe or report that they are less hard working and responsible, for instance, than they really are. However, the fact that similar associations have been found in prospective studies of children and young adults, and that personality measures appear to be persistent over a lifetime, suggest that at least some of the association may be real.

Should these preliminary and tentative findings be confirmed with prospective, longitudinal studies in the future, there are practical implications. Interventions to increase conscientiousness or at least behaviors, habits, and skills characteristic of conscientious individuals may be beneficial. Recognizing deficits in conscientiousness and emotional stability as risk factors for poor economic outcomes may help target other sorts of interventions. Recent findings from behavioral economics suggest that the ability to defeat hyperbolic discounting, e.g., overcome the tendency to put off the start of a savings plan, or to avoid over-reaction to short-term signals may be important to long-term success at retirement saving. Conscientiousness may be another way of measuring that ability. 


\section{References}

Philippa Clarke, Gwenith Fisher, Jim House, Jacqui Smith, and David Weir, Guide to Content of the HRS Psychosocial Leave-Behind Participant Lifestyle Questionnaires: 2004 \& 2006. Documentation Report v2.0 (December 2008).

Cunha, Flavio, and Heckman, James J. (2007). The technology of skill formation. American Economic Review 97(2):31-47 (May, 2007)

Friedman, H. S., Tucker, J. S., Tomlinson-Keasey, C., Schwartz, J. E., \& et al. (1993). Does childhood personality predict longevity? Journal of Personality and Social Psychology, 65, 176-185.

Hampson, S.E., Goldberg, L.R., Vogt, T.M., Dubanoski, J.P. (2007). Mechanisms by which childhood personality traits influence adult health status: Educational attainment and healthy behaviors. Health Psychology, 26, 121-125.

Heckman, J. J., Stixrud, J., \& Urzua, S. (2006). The Effects of Cognitive and Noncognitive Abilities on Labor Market Outcomes and Social Behavior. Journal of Labor Economics,24, 411-482.

Judge, T. A., Higgins, C. A., Thoresen, C. J., \& Barrick, M. R. (1999). The big five personality traits, general mental ability, and career success across the life span. Personnel Psychology, 52, 621-652.

Krueger, R. F., \& Johnson, W. (2008). Behavioral genetics and personality: A new look at the integration of nature and nurture. In L. A. Pervin, O. P. John \& R. W. Robins (Eds.), Handbook of Personality: Theory and Research (3rd ed.). New York: Guilford.

Lachman, M. E., \& Weaver, S. L. (1997). Midlife Development Inventory (MIDI) personality scales: Scale construction and scoring. Unpublished Technical Report. Brandeis University.

Poropat, A. E. (2009). A meta-analysis of the five-factor model of personality and academic performance. Psychological Bulletin, 135, 322-338.

Roberts, B. W., \& DelVecchio, W. F. (2000). The rank-order consistency of personality from childhood to old age: A quantitative review of longitudinal studies. Psychological Bulletin, 126, 3-25.

Roberts, B. W., Kuncel, N. R., Shiner, R., Caspi, A., \& Goldberg, L. R. (2007). The power of personality: The comparative validity of personality traits, socioeconomic status, and cognitive ability for predicting important life outcomes. Perspectives on Psychological Science, 2, 313-345.

Roberts, B. W., Smith, J., Jackson, J. J., \& Edmonds, G. (2009). Compensatory Conscientiousness and Health in Older Couples. Psychological Science.

Terracciano, A., Sanna, S., Uda, M., Deiana, B., Usala, G., Busonero, F., Maschio, A., Scally, M., Patriciu, N., Chen, W., Distel, M. A., Slagboom, P. E., Boomsma, D. I., Villafuerte, S., Śliwerska, E., Burmeister, M., Amin, N., Janssens, A. C. J. W., van Duijn, C. M., Schlessinger, D., Abecasis, G. R., \& Costa, P. T. Jr. (2010). Genome-wide association scan for five major dimensions of personality. Molecular Psychiatry, 15, 647-656. 
Venti, Steven F., Wise, David A. [1998] "The Cause of Wealth Dispersion at Retirement: Choice or Chance?" American Economic Review. 88:2 p.185-91 
TABLE 1. Determinants of Lifetime Social Security Earnings (in logs)

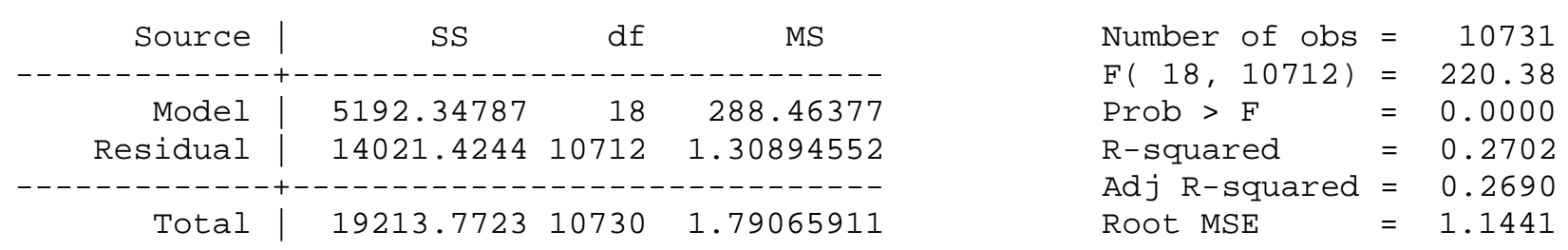

\begin{tabular}{|c|c|c|c|c|c|c|}
\hline loglifeearn | & Coef. & Std. Err. & $\mathrm{t}$ & $P>|t|$ & {$[95 \%$ Conf } & Interval] \\
\hline Birth year & .0051958 & .0022519 & 2.31 & $\odot .021$ & .0007818 & .0096099 \\
\hline Female & -1.150476 & .0251929 & -45.67 & $\odot .00 \odot$ & -1.199859 & -1.101093 \\
\hline Hispanic & -.354105 & .0458927 & -7.72 & $\odot . \odot \odot \odot$ & -.4440632 & -.2641468 \\
\hline Black & -.0434894 & .0367294 & -1.18 & $\odot .236$ & -.1154859 & .0285072 \\
\hline CODA & .097793 & .0553008 & 1.77 & $\odot .077$ & - . . 0106067 & .2061928 \\
\hline HRS & . 2049369 & .0528106 & 3.88 & $\odot .00 \odot$ & .1014183 & .3084556 \\
\hline War Baby & .3049548 & .0717734 & 4.25 & $\odot . \odot \odot \odot$ & .1642655 & .445644 \\
\hline Early Boomer & .2757536 & .0820896 & 3.36 & $\odot .001$ & .1148427 & .4366646 \\
\hline Years of Ed & .047972 & .0047526 & 10.09 & $\odot . \odot \odot \odot$ & . 0386561 & .0572879 \\
\hline Memory & .0331273 & .0144999 & 2.28 & $\odot .022$ & $.0 \odot 47 \odot 47$ & .061549 \\
\hline Mental status| & .0881126 & .0144723 & 6.09 & $\odot . \odot \odot \odot$ & .0597441 & .116481 \\
\hline Numeracy & .0829685 & .0137166 & 6.05 & $\odot .000$ & .0560814 & .1098556 \\
\hline Vocabulary & .0100306 & .0137913 & 0.73 & $\odot .467$ & -.0170029 & .0370641 \\
\hline Agreeableness & -.0024257 & .0146612 & -0.17 & 0.869 & - . 0311643 & .0263129 \\
\hline Extroversion & -.0268077 & .0151834 & -1.77 & $\odot .077$ & - . 0565701 & $.0 \odot 29546$ \\
\hline Neuroticism & - .0516954 & .0119523 & -4.33 & $\odot .00 \odot$ & - . 0751241 & -.0282666 \\
\hline Conscientious & .0903806 & .0136922 & 6.60 & $\odot . \odot \odot \odot$ & .0635413 & .1172199 \\
\hline Openness & -.0129573 & .014729 & -0.88 & 0.379 & - . . 0418288 & .0159143 \\
\hline Intercept & 4.173803 & 4.32077 & $\odot .97$ & 0.334 & -4.295707 & 12.64331 \\
\hline
\end{tabular}

Notes: The dependent variable is the logarithm of total Social security earnings from the linked administrative record. The cognition variables (memory through vocabulary) and personality variables (agreeableness through openness) were all transformed to standardized z-scores so effect sizes represent the effect of a one standard deviation change in the level of those variables. 
TABLE 2. Determinants of Average Annual Social Security Earnings (in \$2006)

\begin{tabular}{|c|c|c|c|c|}
\hline Source I & $d f$ & MS & Number of obs & 10731 \\
\hline & & & $F(18,10712)$ & 385.34 \\
\hline Model | & $1.6220 \mathrm{e}+12$ & $9.0111 e+10$ & Prob > F & $\odot .000 \odot$ \\
\hline Residual & $2.5050 \mathrm{e}+1210712$ & 233848345 & R-squared & 0.3930 \\
\hline 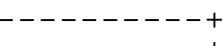 & & & Adj R-squared & 0.3920 \\
\hline Tot & $4.1270 \mathrm{e}+12 \quad 10730$ & 384621598 & Root MSE & 15292 \\
\hline
\end{tabular}

\begin{tabular}{|c|c|c|c|c|c|c|}
\hline avgearn | & Coef. & Std. Err. & $\mathrm{t}$ & $P>|t|$ & {$\left[\begin{array}{lll}95 \% & C c\end{array}\right.$} & Int \\
\hline Birth year & -41.99934 & 30.09862 & $-1.4 \odot$ & 0.163 & -100.9982 & 16.99954 \\
\hline Female & -20083.73 & 336.7316 & -59.64 & $\odot . \odot \odot \odot$ & -20743.78 & -19423.67 \\
\hline Hispanic & -3489.425 & 613.4088 & -5.69 & $\odot . \odot \odot \odot$ & -4691.82 & -2287.031 \\
\hline Black & -1491.524 & 490.9313 & -3.04 & $\odot . \odot \odot 2$ & -2453.841 & -529.2079 \\
\hline CODA & -2027.889 & 739.1583 & -2.74 & $\odot . \odot \odot 6$ & -3476.777 & -579.0019 \\
\hline HRS & -1321.241 & 705.875 & -1.87 & 0.061 & $-27 \odot 4.887$ & 62.40522 \\
\hline War Baby & 1056.489 & 959.3346 & 1.10 & 0.271 & -823.985 & 2936.962 \\
\hline Early Boomer & 262.998 & 1097.223 & 0.24 & 0.811 & -1887.762 & 2413.758 \\
\hline Years of Ed & 1059.593 & 63.52354 & 16.68 & $\odot .00 \odot$ & 935.0749 & 1184.111 \\
\hline Memory & 373.1204 & 193.8082 & 1.93 & 0.054 & -6.779583 & 753.0203 \\
\hline Mental status| & 1047.022 & 193.4392 & 5.41 & $\odot .00 \odot$ & 667.8455 & 1426.199 \\
\hline Numeracy & 1822.879 & 183.3385 & 9.94 & $\odot .00 \odot$ & 1463.502 & 2182.257 \\
\hline Vocabulary & 693.3905 & 184.3367 & 3.76 & $\odot .000$ & 332.0564 & 1054.725 \\
\hline Agreeableness & -344.8348 & 195.9632 & -1.76 & 0.078 & -728.9589 & 39.2894 \\
\hline Extroversion & -799.0713 & 202.9442 & -3.94 & $\odot .000$ & -1196.88 & -401.263 \\
\hline Neuroticism & -697.8328 & 159.7566 & -4.37 & $\odot . \odot \odot \odot$ & -1010.985 & -384.6802 \\
\hline Conscientious| & 1536.403 & 183.0125 & 8.40 & $\odot .00 \odot$ & 1177.665 & 1895.142 \\
\hline Openness & -4.730365 & 196.8699 & -0.02 & 0.981 & -390.6319 & 381.1711 \\
\hline Intercept & 130375.5 & 57752.06 & 2.26 & $\odot .024$ & 17170.79 & 243580.3 \\
\hline
\end{tabular}


TABLE 3. Determinants of Years with Social Security Earnings

\begin{tabular}{|c|c|c|c|c|}
\hline Source I & $d f$ & MS & Number of obs & $\begin{array}{r}10731 \\
=154.90\end{array}$ \\
\hline Model & 205236.881 & 11402.049 & Prob $>\mathrm{F}$ & 0.0000 \\
\hline Residual & 788521.01110712 & 73.6109981 & R-squared & 0.2065 \\
\hline & & & Adj R-squared & $\odot .2052$ \\
\hline To & $57.893 \quad 10730$ & 92.6149015 & Root MSE & 8.5797 \\
\hline
\end{tabular}

\begin{tabular}{|c|c|c|c|c|c|c|}
\hline capylb | & Coef. & Std. Err. & $\mathrm{t}$ & $P>|t|$ & [95\% Conf. & Interval] \\
\hline Birth year & 2190224 & .0168869 & 12.97 & $\odot . \odot \odot \odot$ & 1859209 & 252124 \\
\hline Female & -6.456966 & .1889244 & -34.18 & $\odot . \odot \odot \odot$ & -6.827292 & -6.086639 \\
\hline Hispanic & -3.392064 & .3441551 & -9.86 & $\odot .000$ & -4.066671 & -2.717456 \\
\hline Black & .0947599 & .2754387 & 0.34 & $\odot .731$ & -.445151 & .6346707 \\
\hline CODA & 1.836634 & .4147073 & 4.43 & $\odot . \odot \odot \odot$ & 1.023731 & 2.649537 \\
\hline HRS & 3.029637 & .3960336 & 7.65 & $\odot . \odot \odot \odot$ & 2.253337 & 3.805936 \\
\hline War Baby & 3.004431 & .5382379 & 5.58 & $\odot . \odot \odot \odot$ & 1.949385 & 4.059477 \\
\hline Early Boomer & 2.645412 & .6156005 & 4.30 & $\odot . \odot \odot \odot$ & 1.438721 & 3.852103 \\
\hline Years of Ed & .1253388 & .0356401 & 3.52 & $\odot . \odot \odot \odot$ & .0554776 & .1952 \\
\hline Memory & .1520867 & .1087367 & 1.40 & $\odot .162$ & -.0610574 & .3652309 \\
\hline Mental status| & .4339663 & .1085297 & 4.00 & $\odot .00 \odot$ & .221228 & .6467047 \\
\hline Numeracy & .3315898 & .1028627 & 3.22 & $\odot . \odot \odot 1$ & .1299599 & .5332197 \\
\hline Vocabulary & -.1751131 & .1034227 & -1.69 & $\odot . \odot 9 \odot$ & -.3778409 & .0276147 \\
\hline Agreeableness & -.0215865 & .1099458 & -0.20 & 0.844 & -.2371007 & 1939277 \\
\hline Extroversion & 1291691 & .1138625 & 1.13 & $\odot .257$ & - . .0940226 & .3523607 \\
\hline Neuroticism & -.2555529 & .089632 & -2.85 & $\odot . \odot \odot 4$ & -.4312482 & -.0798576 \\
\hline Conscientious| & .3643869 & .1026798 & 3.55 & $\odot .00 \odot$ & .1631154 & .5656583 \\
\hline Openness & -.1671233 & .1104545 & -1.51 & 0.130 & -.3836347 & .049388 \\
\hline Intercept & -390.1695 & 32.40199 & -12.04 & $\odot . \odot \odot \odot$ & -453.6834 & -326.6556 \\
\hline
\end{tabular}


TABLE 4. Test of Interaction Effects of Conscientiousness and Neuroticism

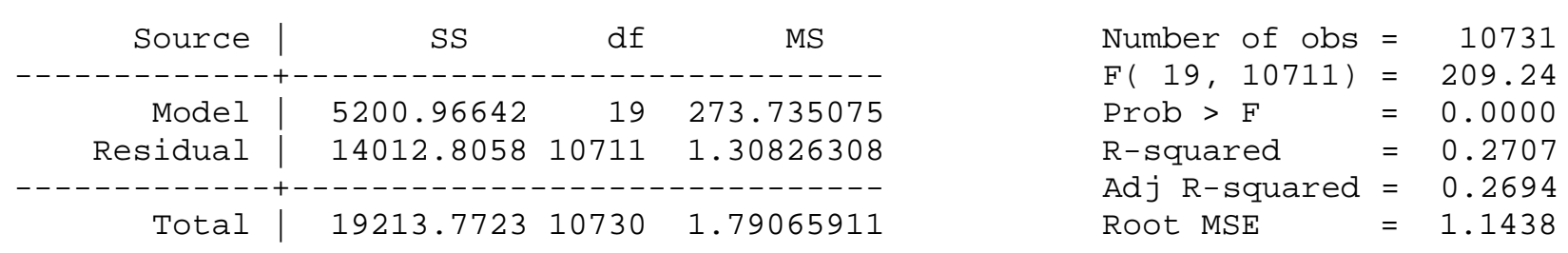

\begin{tabular}{|c|c|c|c|c|c|c|}
\hline loglifeearn & Coef. & Std. Err. & $t$ & $P>|t|$ & {$[95 \%$ Conf } & Int \\
\hline rth year & .0052949 & .002 & 2.35 & 0.019 & 814 & $.0 \odot 970$ \\
\hline Female & -1.150394 & .0251863 & -45.68 & 0.000 & -1.199764 & -1.101024 \\
\hline Hispanic & -.3568577 & .0458933 & -7.78 & 0.000 & -.446817 & -.2668984 \\
\hline Black & -.0454883 & .0367281 & -1.24 & 0.216 & -.1174822 & .0265057 \\
\hline CODA & .0998574 & .0552922 & 1.81 & 0.071 & - . .0085256 & .208240 \\
\hline HRS & .207074 & .0528034 & 3.92 & $0.00 \odot$ & .1035695 & .3105785 \\
\hline War Baby & .3050447 & .0717547 & 4.25 & 0.000 & .1643921 & .4456973 \\
\hline Early Boomer & .2760857 & .0820683 & 3.36 & 0.001 & .1152165 & .4369549 \\
\hline Years of Ed & .0479114 & .0047514 & 10.08 & 0.000 & .0385978 & .057225 \\
\hline Memory & .0322969 & .014 & 2.23 & 0.026 & .0038747 & .0607191 \\
\hline Mental status| & .0869713 & .0144754 & 6.01 & $0.00 \odot$ & .0585969 & .1153457 \\
\hline Numeracy & .0826698 & .0137135 & 6.03 & 0.000 & .0557887 & .1095509 \\
\hline Vocabulary & .0092836 & .0137908 & 0.67 & 0.501 & -.0177489 & .0363161 \\
\hline Agreeableness & - . .0018239 & .0146592 & -0.12 & 0.901 & - . .0305587 & .0269108 \\
\hline Extroversion & -.0277634 & 0151841 & -1.83 & 0.068 & -.057527 & 001 \\
\hline Neuroticism & -.0513467 & . 01195 & -4.30 & 0.000 & -.0747709 & -.0279225 \\
\hline Conscientious & .0864142 & 0137756 & 6.27 & $\odot .0 \odot \odot$ & .0594114 & .113417 \\
\hline Openness & - .0106153 & .0147534 & -0.72 & 0.472 & - .0395347 & .0183041 \\
\hline $\mathrm{C} \times \mathrm{N}$ & .0271748 & .0105876 & 2.57 & 0.010 & .0064212 & .0479284 \\
\hline Intercept & 3.988822 & 4.320245 & 0.92 & 0.356 & -4.479659 & 12.457 \\
\hline
\end{tabular}


TABLE 5. Determinants of Wealth (in logs), Married Couples Only

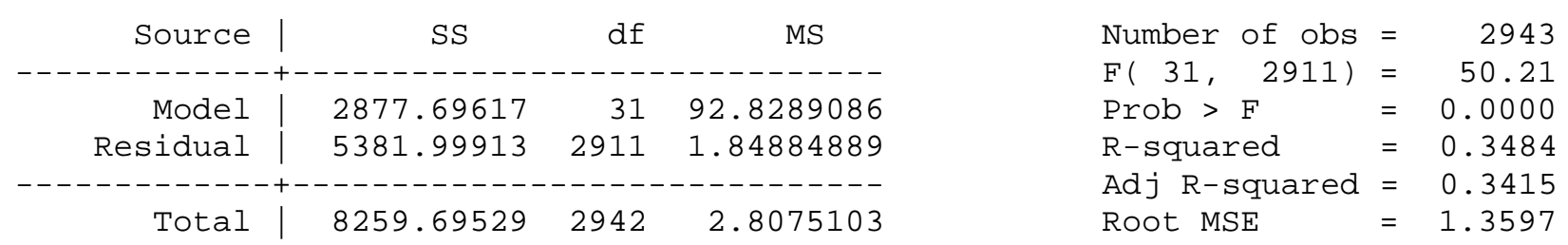

\begin{tabular}{|c|c|c|c|c|c|c|}
\hline logwlth & Coef. & Std. Err. & $\mathrm{t}$ & $P>|t|$ & [95\% Conf. & al] \\
\hline M Birth year & -.0222554 & .0062354 & -3.57 & 0.000 & -.0344816 & -.0100291 \\
\hline F Birth year & - . .0219361 & .0052288 & -4.20 & 0.000 & -0321886 & -.0116835 \\
\hline M Yrs of Ed & .078965 & .0114186 & 6.92 & $0.00 \odot$ & .0565757 & .1013544 \\
\hline F Yrs of Ed & .0792289 & .0129619 & 6.11 & 0.000 & .0538135 & .1046443 \\
\hline M Hispanic & -.1523346 & .1831715 & -0.83 & 0.406 & -.5114936 & .2068243 \\
\hline M Black & -.9994283 & .2599213 & -3.85 & 0.000 & -1.509077 & -.4897799 \\
\hline F Hispanic & $-.0 \odot 48588$ & .1800458 & $-\odot .03$ & 0.978 & -.3578889 & .3481713 \\
\hline F Black & .2333524 & .2632706 & $\odot .89$ & 0.375 & -.2828631 & .7495678 \\
\hline CODA & - . .0224381 & .1472678 & -0.15 & 0.879 & -.3111978 & .2663216 \\
\hline HRS & .2097803 & .1453885 & 1.44 & 0.149 & - . .0752944 & .494855 \\
\hline War Baby & .4316667 & .1910285 & 2.26 & 0.024 & .0571019 & .8062315 \\
\hline Early Boomer & - . .010184 & .2239768 & -0.05 & 0.964 & -.4493531 & . 4289851 \\
\hline M Memory & .0259523 & .0292758 & 0.89 & 0.375 & - . .0314511 & .0833556 \\
\hline F Memory & .0431381 & .0291101 & 1.48 & 0.138 & -.0139404 & 2166 \\
\hline M Mental stat| & .0650549 & .030854 & 2.11 & 0.035 & .004557 & .1255528 \\
\hline F Mental stat| & .0893812 & .0308603 & $2.9 \odot$ & 0.004 & .028871 & .1498913 \\
\hline M Numeracy & .1430477 & .0314014 & 4.56 & 0.000 & .0814764 & .2046189 \\
\hline F Numeracy & .0409656 & .0302346 & 1.35 & 0.176 & -0183177 & .1002489 \\
\hline M Vocabulary & - . 0008345 & .0306799 & $-\odot .03$ & 0.978 & - . .0609911 & 322 \\
\hline M Vocabulary & .0959712 & .0296893 & 3.23 & 0.001 & .037757 & 855 \\
\hline M Agreeable & -.1048647 & .0335139 & -3.13 & 0.002 & -.170578 & -.0391513 \\
\hline F Agreeable & -.083246 & .0319437 & -2.61 & 0.009 & -.1458805 & -.0206114 \\
\hline M Extrovert & .0003341 & .0355338 & 0.01 & 0.992 & - .0693398 & .070008 \\
\hline F Extrovert & . 0852344 & .0331303 & 2.57 & 0.010 & .0202733 & 1501956 \\
\hline M Neurotic & - . .0397125 & .0280117 & -1.42 & 0.156 & -.0946372 & .0152123 \\
\hline F Neurotic & - . 0132398 & .0277783 & -0.48 & 0.634 & -.067707 & .0412273 \\
\hline M Conscient & .1482636 & .0314658 & 4.71 & $0.00 \odot$ & .0865661 & .2099612 \\
\hline F Conscient & .1497793 & .0308034 & 4.86 & 0.000 & .0893807 & .210178 \\
\hline M Openness & - .0065854 & .0348203 & -0.19 & 0.850 & -.0748604 & .0616896 \\
\hline F Openness & -.0358617 & .0325901 & -1.10 & 0.271 & - . .0997637 & .0280403 \\
\hline Log Life Earn & . 4151281 & .0405899 & 10.23 & 0.000 & .3355403 & .4947158 \\
\hline Intercept & 89.89936 & 11.69065 & 7.69 & 0.000 & 66.97658 & 112.8221 \\
\hline
\end{tabular}


TABLE 6. Determinants of Log Ratio of Wealth to Lifetime Social Security Earnings, Married Couples

\begin{tabular}{|c|c|c|c|c|c|}
\hline Source & SS & $d f$ & MS & Number of obs & $\begin{array}{r}2922 \\
24.43\end{array}$ \\
\hline Model & 1392.9165 & 30 & 46.4305499 & Prob > F & 0.0000 \\
\hline Residual & 5493.92844 & 2891 & 1.90035574 & R-squared & 0.2023 \\
\hline Total & 6886.84494 & 2921 & 2.35770111 & $\begin{array}{l}\text { Adj R-squared } \\
\text { Root MSE }\end{array}$ & $\begin{array}{l}0.1940 \\
1.3785\end{array}$ \\
\hline
\end{tabular}

\begin{tabular}{|c|c|c|c|c|c|c|}
\hline lograt & Coef. & Std. Err. & $\mathrm{t}$ & $P>|t|$ & [95\% Conf. & Interval] \\
\hline M Birth year & -.0236723 & .0063382 & -3.73 & $0.00 \odot$ & - . .0361002 & -.011244 \\
\hline F Birth year & - . .0210238 & .0053361 & -3.94 & 0.000 & -.0314867 & -.0105608 \\
\hline M Yrs of Ed & .0623526 & .0116056 & 5.37 & 0.000 & .0395966 & .0851086 \\
\hline F Yrs of Ed & .0670068 & .0132473 & 5.06 & $0.00 \odot$ & .0410317 & .0929819 \\
\hline M Hispanic & .0503145 & .1874498 & 0.27 & 0.788 & -.3172343 & .4178633 \\
\hline M Black & -.7030698 & .2770656 & -2.54 & 0.011 & -1.246336 & -.1598038 \\
\hline F Hispanic & .1640538 & .1845324 & $\odot .89$ & 0.374 & -.1977746 & 822 \\
\hline F Black & .0926252 & .279784 & 0.33 & 0.741 & -.4559711 & .6412214 \\
\hline CODA & -.2264086 & .1496116 & -1.51 & 0.130 & -.5197647 & .0669476 \\
\hline HRS & - .0442976 & .1477366 & -0.30 & 0.764 & -.3339773 & .2453821 \\
\hline War Baby & .1143555 & .1941758 & 0.59 & 0.556 & -.2663814 & .4950925 \\
\hline Early Boomer & -.2650153 & .2279834 & -1.16 & 0.245 & -.7120417 & 111 \\
\hline M Memory & .0121206 & .0297842 & 0.41 & 0.684 & -.0462799 & 211 \\
\hline F Memory & .0324176 & .0296051 & 1.09 & 0.274 & -.0256317 & .0904669 \\
\hline M Mental stat & .0290862 & .0316201 & 0.92 & 0.358 & -.032914 & .0910863 \\
\hline F Mental stat & .0627204 & .0314854 & 1.99 & 0.046 & .0009844 & .1244564 \\
\hline M Numeracy & .131621 & .03192 & 4.12 & 0.000 & .0690328 & .1942092 \\
\hline F Numeracy & .0052243 & .030 & 0.17 & 0.865 & - .0549164 & 365 \\
\hline M Vocabulary & -.0051175 & .0312049 & -0.16 & 0.870 & -.0663036 & 685 \\
\hline M Vocabulary & .0703174 & $.03 \odot 2876$ & 2.32 & 0.020 & .0109299 & .1297049 \\
\hline M Agreeable & -.1122329 & .0340756 & -3.29 & 0.001 & -.1790478 & - . . 045418 \\
\hline F Agreeable & -.1145767 & .0325399 & -3.52 & 0.000 & -.1783805 & -.050773 \\
\hline M Extrovert & .0274599 & .0360996 & 0.76 & 0.447 & -.0433237 & .0982435 \\
\hline F Extrovert & .095314 & .0337114 & 2.83 & 0.005 & .0292131 & 1614148 \\
\hline M Neurotic & - . .059423 & .02 & -2.08 & 0.037 & -.1153229 & -.00 \\
\hline F Neurotic & - .0150061 & .0282812 & -0.53 & 0.596 & - . .0704594 & .0404472 \\
\hline M Conscient & .1217312 & .0319909 & 3.81 & $0.00 \odot$ & .059004 & .1844583 \\
\hline F Conscient & .1166399 & .0313155 & 3.72 & 0.000 & .055237 & .1780428 \\
\hline M Openness & - . .๑०९७785 & .0355538 & $-\odot . \odot \odot$ & 0.998 & - . . 0697918 & .0696348 \\
\hline F Openness & - . .0262735 & . 03321 & -0.79 & 0.429 & - .0913912 & .0388442 \\
\hline Intercept & 83.07545 & 11.91189 & 6.97 & 0.000 & 59.7188 & 106.4321 \\
\hline
\end{tabular}




\section{Appendix}

\section{Adjectival markers of Big Five Personality in the HRS}

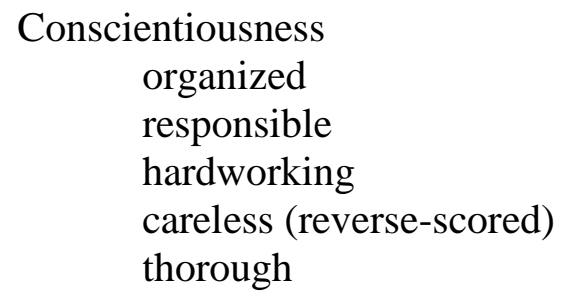

Neuroticism

moody

worrying

nervous

calm

Agreeableness

helpful

friendly

warm

caring

softhearted

sympathetic

Openness to Experience

creative

imaginative

intelligent

curious

broad-minded

sophisticated

Extraversion

outgoing

lively

active

talkative

adventurous 